TITLE:

\title{
HATAKEZIMA ISLAND WILL SUCCESSFULLY BE CONSERVED FOR MARINE BIOLOGICAL RESEARCHES
}

\author{
$\operatorname{AUTHOR}(\mathrm{S}):$ \\ Tokioka, Takasi
}

\section{CITATION:}

Tokioka, Takasi. HATAKEZIMA ISLAND WILL SUCCESSFULLY BE CONSERVED FOR MARINE BIOLOGICAL RESEARCHES. PUBLICATIONS OF THE SETO MARINE BIOLOGICAL LABORATORY 1969, 17(1): 1-6

\section{ISSUE DATE:}

1969-05-30

URL:

http://hdl.handle.net/2433/175570

RIGHT: 


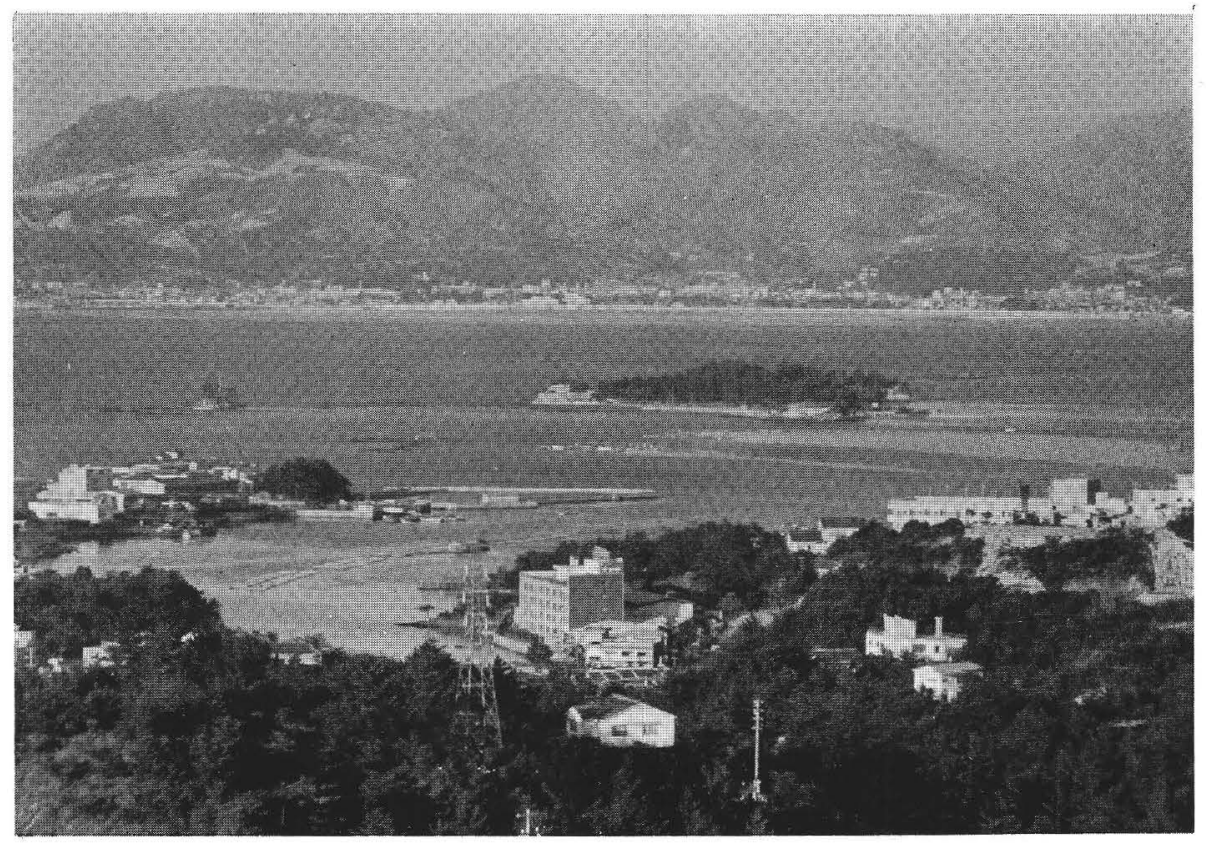

\section{HATAKEZIMA ISLAND WILL SUCCESSFULLY BE CONSERVED FOR MARINE BIOLOGICAL RESEARCHES}

Hatakezima is a small island of $26529 \mathrm{~m}^{2}$ situated in Tanabe Bay on the west coast of Kii Peninsula which is projected out south from the Pacific coast of the middle of Honsyû Island, the largest of main islands of Japan. The island consists of Hatakezima Proper which is roughly triangular with about $250 \mathrm{~m}$ long base on the north and of $25981 \mathrm{~m}^{2}$ and lovely Komaruzima Islet of $548 \mathrm{~m}^{2}$, both are connected with each other by about $150 \mathrm{~m}$ long series of rocky reefs which mostly submerge at high tide. The level mark of the National Geographical Institute on the hill at the northwest corner of Hatakezima Proper is sited at $33^{\circ} 41^{\prime} 37.5^{\prime \prime} \mathrm{N}$ and $135^{\circ} 21^{\prime} 56.9^{\prime \prime}$ E. In addition, at low tide of the spring tide, there will be exposed a vast rocky reef on the west of Komaruzima. The total of intertidal zones thus exposed at low tide of about $30 \mathrm{~cm}$ high will be nearly as extensive as the area of the island itself. The shores of Hatakezima and Komaruzima are chiefly rocky, of the Tertiary sand stone, but a larger part of the west shore of Hatakezima Proper and partly its east shore and southern point form sandy beaches containing a large amount of shell fragments.

Above photograph: Hatakezima consists of Hatakezima Proper (on the right) and Komaruzima (on the left), viewed from the mountain slope south of Tanabe Bay at high tide. Several pearl oyster rafts are seen below. (Araga photo.)

Publ. Seto Mar. Biol. Lab., XVII (1), 1-6, 1969. 


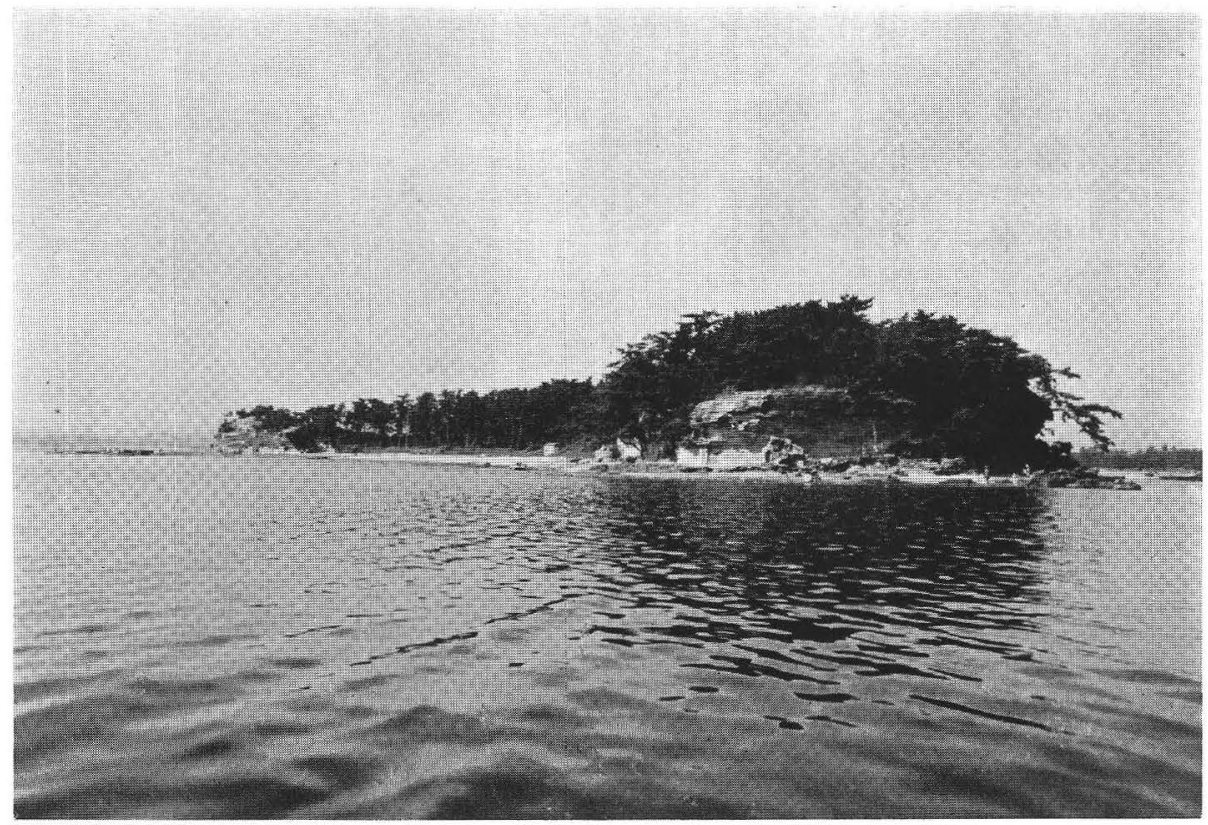

Southeast point of Hatakezima Proper. (ARAgA photo.)

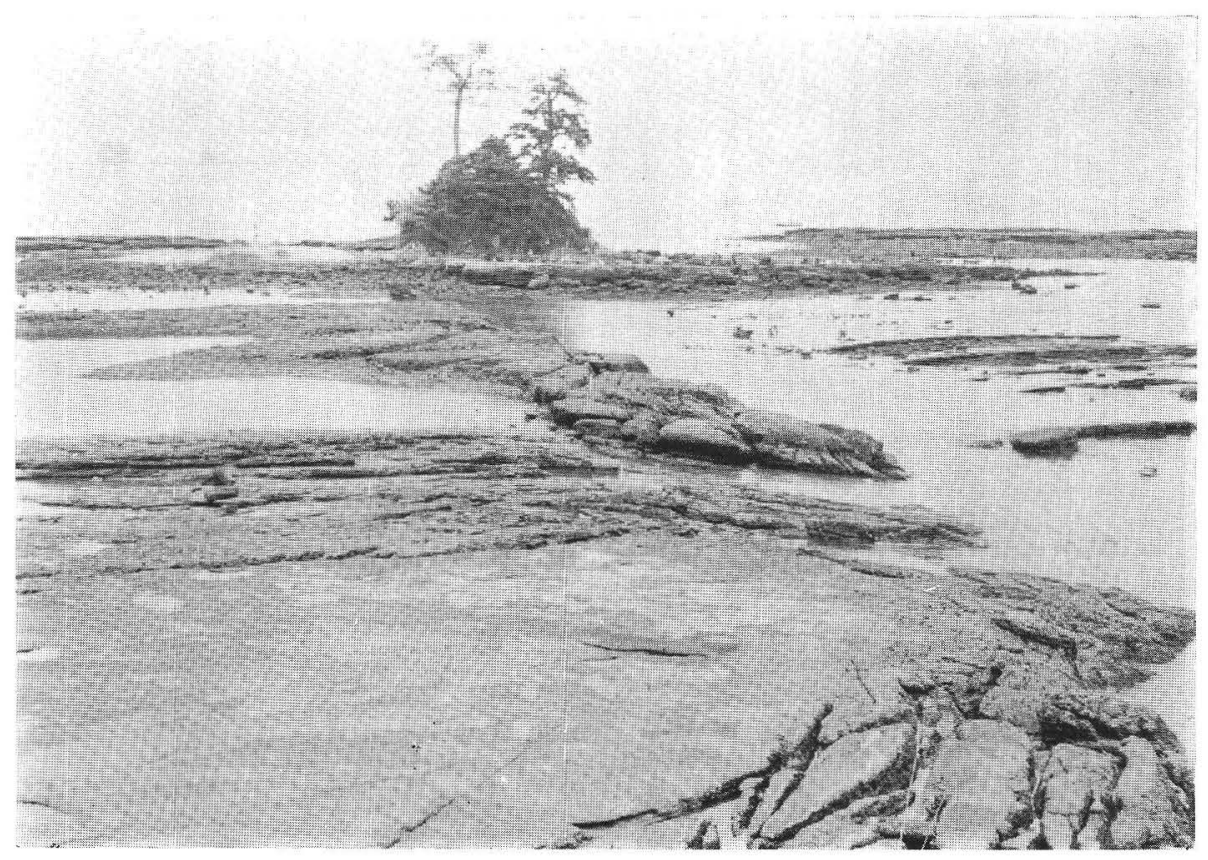

Komaruzima viewed from the northwest corner of Hatakezima Proper. Extensive western reefs are seen on the right of the islet. (FusE photo.) 
The intertidal zones are also mostly rocky, but there are a wide sandy to sandy muddy area on the south of the zone between Hatakezima Proper and Komaruzima, and gravel areas around Komaruzima. Of the rocky reefs, the western-most reef is the largest, and there is a boulder area between this western reef and Komaruzima. The rocky reefs are differentiated into slopes of different inclinations, flats, cliffs, and crevices of various scales. The eastern half of the sandy and muddy area is covered with a marine phanerogam Halophila ovalis Hook and the western sandy area is a wellknown ground in this district of an acorn worm Balanoglossus misakiensis Kuwano. The Halophila-zone continues north along the south of the northwest corner of Hatakezima Proper to an Enteromorpha-area generally covered with green algae Enteromorpha spp. and harbouring a big population of a snail Batillaria multiformis (Lischke). An outcrop of the dike of shale, which is running out from the ancient mud volcano, is found just south of Komaruzima and this offers the place for some boring animals.

The island and reefs are situated so that they shelter the southeastern part of the bay, which is topographically very complicated and filled with somewhat stagnant water of the grade containing an inlet-water chaetognath Aidanosagitta delicata Tокіока. Thus, the west and north shores of the reef area including the islands are washed by the clear oceanic water, while the east and south shores face the rather turbid inlet water.

As shown apparently by the topography and situation, the shores of the reef area including the islands afford naturally manifold niches for marine organisms. Indeed, the rich littoral fauna and flora of Tanabe Bay, which have been referred to repeatedly, are mostly represented intensively in this area, except for various kinds of octocorals and scleractinian corals which are generally confined to the areas exposed to the strong flowing of the oceanic water. For instance, usually about ten echinids can be observed during a tour of the area, which can be done very easily and safely in about two hours; they are Diadema setosum (LesKe), Mespilia globulus (Linnaeus), Temnotrema sculptum A. Agassiz, Temnopleurus toreumaticus (LESKE), Toxopneustes pileolus (LAmARCK), Tripneustes gratilla (Linnaeus), Hemicentrotus pulcherrimus (A. Agassiz), Pseudocentrotus depressus (A. Agassiz), Anthocidaris crassispina (A. Agassiz), Echinostrephus aciculatus A. Agassiz, Echinometra mathaei (Blainville), and Peronella japonica Mortensen. Several of them are available as the material for researches or instruction. A fluorescent pennatulid Cavernularia obesa M. EDWARDS \& HAINE, a pretty purplish sea anemone Cerianthus filiformis CARLgRen, and a tropical black sea-cucumber Holothuria leucospilota (BRANDT) are met with most easily and frequently in or around this area in Tanabe Bay and adjacent region. The outline of the rich intertidal fauna of the island will be published in a future paper in detail.

For these reasons, Hatakezima Island has been for ages one of the most important places indispensable for researches and education carried out at the laboratory. It is impossible to estimate how many biologists owe the island for some parts of their 


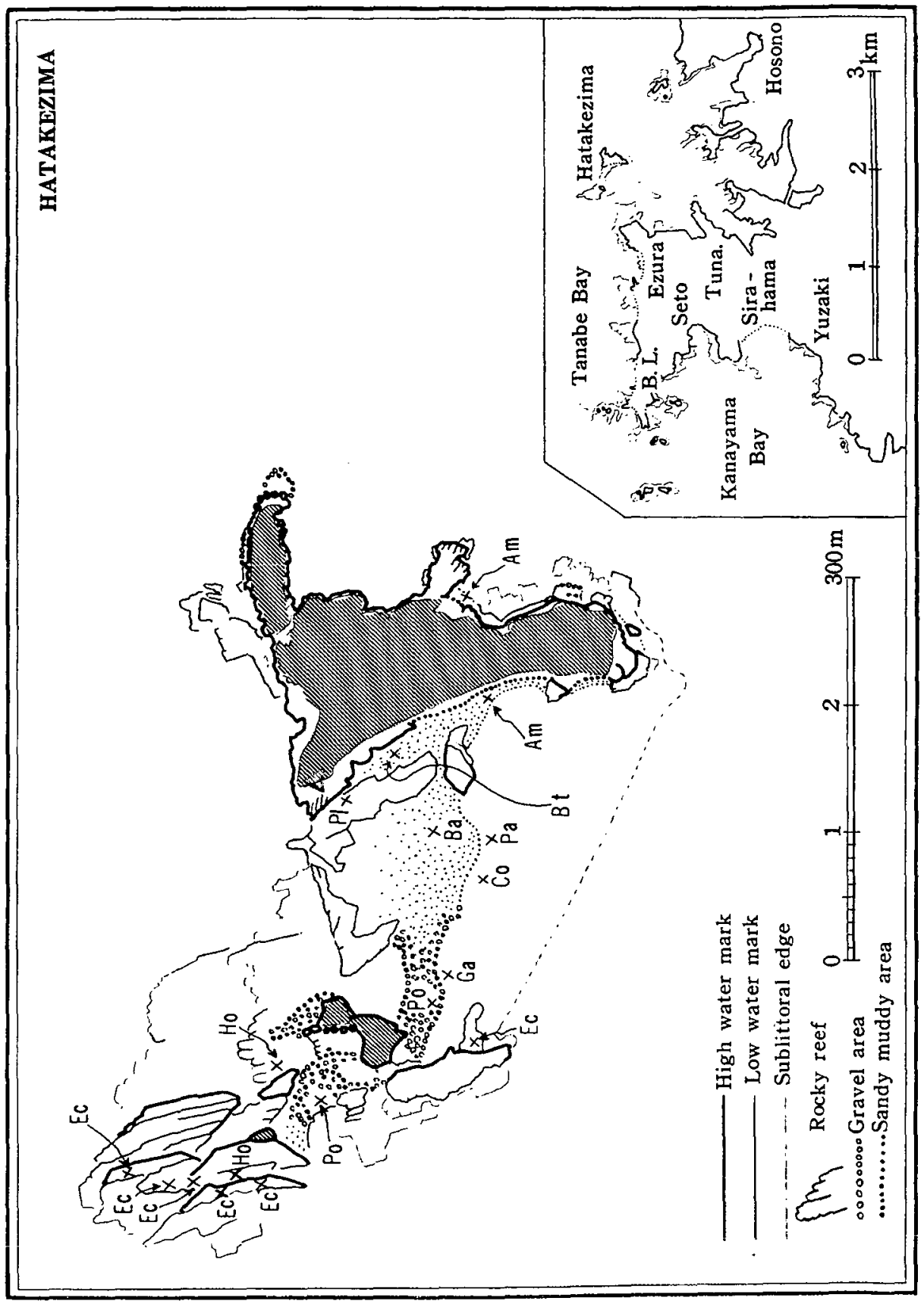

Map of Hatakezima, showing sites of some prominent animal populations. Am--Atactodea striata (GMElin), Ba-Balanoglossus misakiensis KuWANo, Bt-Batillaria multiformis (LIsCHKE), CoConomurex luhuanus (LinnaEus), Ec-echinids colony, Ga-Gafrarium divaricatum (GMelin), HoHolothuria leucospilota (BRANDT), $\mathrm{Pa}$-Paphia amabilis (PhILIPPI), PI-Planaxis sulcatus (BorN), PoPolycheira rufescens (BRANDT), $\triangle$-level mark. Shaded are areas not submerged. (Modified from Токіока 1963) 
successful careers.

Hatakezima Island had ever been possessed by the former village of Seto which is now the northern district of the town of Sirahama, but it was presented in October 1921 to the late Marquis R. Tokugawa in direct descent from the feudal lord in the Tokugawa Era, of the Province of Kii which is now Wakayama Prefecture. It was then succeeded by a local bank, Kiyô Bank, in October 1923 and later in February 1945 by three persons in the prefecture. And in January 1966, the island was succeeded by an estate agent to establish there a facility something like a casino; and the plan of building the "Hawaiian Paradise" was completed by a recreation company, the Daiwa Kankô Co. Ltd. at Kôbe, in April of the same year. Shocked to the bone at this news, the laboratory immediately began a very troublesome campaign to check that plan. Appeals to the president of the company or to the prefectural governor had been made repeatedly, directly or indirectly through mass communication. The first negotiation was held in September between the company and laboratory, and in the beginning of November Mr. S. YONEDA, the president of the company, made official comment to give up the above-mentioned plan.

Then on February 28, 1967, a request was made by the company to the president of the Kyotto University for the purchase of the island by the government. Very fortunately, followed this the appeals from or efforts of the universities or colleges which were sending researchers or students to the laboratory (Ôsaka University, Ôsaka Kyôiku Daigạku, Kyôto Kyôiku Daigaku, Ôsaka City University, and Kôbe University), the societies and congresses concerning biology or natural sciences (Zoological Society of Japan; Ecological Society of Japan; Natural History Society of Wakayama Prefecture; Congress of National Marine Biological Laboratories and Limnological Stations, especially the chairman Prof. M. Sugryama; and Japan Congress of Sciences), and some sympathizers (Prof. T. KAYAMA of Wakayama University, Messrs. K. SASAKI, T. TAYA, H. OnOdera, M. URA, and the Congressman Mr. T. Hayakawa in this region, Dr. T. TAmura of the Marine Park Centre in Tôkyô, and Mr. Y. Tsutsur in Osaka). And it was published on January 13, 1968 that the price for the island was included in the 1968 budget of the Kyôto University. Generally in this country, however, the government estimation of any real estate is far to the current price. Thus, further difficult negotiations had been repeated between the company and the university till December 1968, when they came to an agreement and the island was registered officially as a national property on the 25 th. On February 10, 1969, the university published that the island would be maintained as the Experimental Field of the Seto Marine Biological Laboratory.

Throughout the efforts of securing Hatakezima Island, we became aware very sorrily that only the voices of public manifested directly or through mass communication or statements of any organizations were powerful for the conservation of nature for natural history researches. We hope very sincerely that in future even a tiny part of political efforts will be spared for the conservation of nature of the sea for the marine 
biological researches in this country.

As readily seen, the present short paper is prepared to note in it, with our hearty thanks, the great favours done by the gentlemen and various organizations mentioned above for the purchase of the island. In addition to those, the former prefectural governor Mr. S. ONo contributed much to check the plan of the company by intentionally hesitating to permit the company to utilize any part of the sea surface around the island. The former laboratory director Prof. M. Ichikawa and the present director Prof. M. Morishita, to whom the laboratory director was merely a temporal additional post, were so kind to take willingly troubles concerning Hatakezima Island, which were evidently much greater than those met with in maintaining their own chairs in Kyôto. Our gratitude to these three gentlemen is due.

Lastly our sincere thanks to the president of the Daiwa Kankô Co. Ltd. Mr. S. Yoneda and the chief member of the company directorate Mr. T. Murata, on whose good will the Hatakezima Experimental Field of the Seto Marine Biological Laboratory was established.

TAKASI TOKYOKA (March 22, 1969). 